\title{
DP and mandatory determiners in article-less Serbo-Croatian
}

\author{
Branimir Stanković \\ University of Niš, Serbia \\ branimir.stankovic@filfak.ni.ac.rs
}

\begin{abstract}
Although it lacks grammaticalized categories of definite and indefinite articles and its "bare" nouns are (usually) ambiguous between a definite and indefinite interpretation, Serbo-Croatian has appropriate lexical items for marking discourse-old and discourse-new nominal referents. I demonstrate that there are contexts in which use of these discourse markers is obligatory for obtaining the intended reading, as the "bare" nominal phrase would unambiguously be interpreted as definite or indefinite, depending on the context. More importantly, when present, these discourse markers block left branch and adjunct extractions from the rest of the NP, indicating that a determiner phrase might be projected, even in an article less language.
\end{abstract}

Keywords: DP; Serbo-Croatian; determiners; definiteness; articles

\section{Introduction}

There is an extensive body of linguistic literature on the issue of how appropriate is it to apply a determiner phrase (DP) model to languages that lack obligatory determiners, i.e., languages that lack grammaticalized definite and/or indefinite articles in their noun phrases (NP), such as SerboCroatian (henceforth "SC") (pro DP papers: Progovac 1988; Leko 1999; Aljović 2000; 2002; Kuna 2003; Rutkowsky \& Progovac 2005; Frleta 2005; Pereltsvaig 2007; Caruso 2011; 2012; Arsenijević fortcoming; Stanković 2014; 2015; 2016a;b; forthcoming; papers contra DP: Corver 1990; 1992; Zlatić 1997; 1998; Trenkić 2004; Boškovič 2008; 2012; Boškovič \& Gajewski 2011; Despić 2011; 2013; Runić 2013). Although these papers differ in the argumentation used in favor of the DP or simple "bare" NP model, they are almost unanimous in the appraisal that in article-less languages bare NPs are ambiguous between an indefinite and definite interpretation.

However, in this paper, I will demonstrate that in certain types of contexts, bare NPs are not ambiguous, and as a result, the speaker is compelled to use some kind of a discourse marker of definiteness or indefiniteness in order to obtain the intended reading of the used nominal expression. This discourse marker can be: an indefinite pronoun, such as 
jedan 'a(n), one', neki 'some'; a demonstrative/anaphoric pronoun, such as ovaj 'this', taj 'that', onaj 'that'; or an adjective, such as pomenuti '(the) mentioned, navedeni '(the) stated', imenovani 'named', dati 'given', isti 'same', izvesni 'certain' or odredeni 'particular'.

These mandatory determiners, as I will refer to them, are discourse markers and not genuine definite/indefinite articles, required by syntax. Nevertheless, when present in the nominal expression, these items behave exactly like articles - they are at the front of the noun phrase and they block left branch and adjunct extractions, which are features typically associated with definite articles and DPs. These facts will be seen as an indication that, at least in certain contexts, DP can be projected even in an article-less language, such as SC.

Once we adopt this possibility, certain other phenomena can easily be explained. For instance, nominal expressions cannot be modified by restrictive post-nominal modifiers in epithets in case there are no definite determiners, because the modified NP gets an indefinite interpretation. On the other hand, nominal expressions with pre-nominal modifiers (can) have a definite reading. This fact will be analyzed as an indication that even in article-less SC a [+definite] feature needs to be checked in DP, which can trigger a movement of a post nominal modifier to a pre-nominal position, in the absence of an appropriate definite determiner.

The paper is organized as follows. In section 2 we will get acquainted with the main arguments against a DP-analysis of SC nominal expressions. In section $3 \mathrm{I}$ introduce novel data from SC, concerning the obligatory use of definite and indefinite markers in certain contexts. In section 4 I will show that these mandatory discourse markers behave exactly like articles in languages with these categories - most importantly, they block left branch and adjunct extraction, which indicates that they are located in some functional projection of the D type. Section 5 is dedicated to further examination of the explanatory adequacy of the DP model, when it comes to post-nominal restrictive modification in epithets, and their non-ambiguous indefinite interpretation. Section 6 concludes the paper.

\section{Bare NP analysis for SC nominal expressions}

SC, like other Slavic languages (except for Macedonian, Bulgarian and the Serbian Timok-Lužnice dialect, which are all part of the Balkan Sprachbund), has no grammaticalized definite and indefinite articles. As a result, a speaker of SC is not obliged to use any kind of morphologically or syntactically encoded information about the referential status (in the tradition 
of Heim 1983), nor the uniqueness status (Russell 1905) ${ }^{1}$ of the nominal referent in the relevant discourse. ${ }^{2}$ Hence, the bare nouns in SC are (most often, but not always, as will be demonstrated in the following section) ambiguous between the definite, indefinite or generic interpretation (1).
(1) Profesor podučava studenta.
(ambiguous)
professor teaches student-ACC.SG
'A/The professor is teaching a/the student.' (indefinite/definite)
'Professors teach students.'
(generic)

The fact presented in (1) is not the only reasonable argument to dismiss a DP analysis of SC nominals. Following Corver's (1990; 1992) interpretation of Czech and Polish data, Zlatić (1997; 1998) points out some important empirical insights into the morphology and syntax of SC nominal expressions. First of all, all D-elements in SC decline like adjectives, and not nouns (2). Secondly, in the appropriate context, these items can follow the noun (3a), including the situations where the adjective or the determiner is post-positioned, leaving the noun in between $(3 b)-(3 c)$. Notice that the latter two examples cannot be analyzed as instances of simple N-to-D movement. ${ }^{3}$ Finally, like regular adjectives, SC determiners can be extracted from within the noun phrase, which is generally ungrammatical in languages with articles: ${ }^{4}$

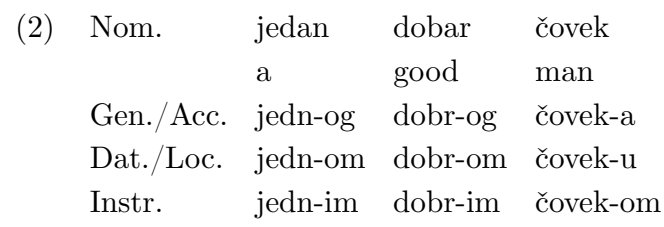

${ }^{1}$ Schwartz (2009) demonstrates that both semantic approaches are important for an accurate description of the use of what are referred to as strong and weak definites in German.

${ }^{2}$ An important exception to this claim would be the distribution of the definite and indefinite adjectival aspect (usually labeled long and short adjective forms), which will be discussed in section 5 .

${ }^{3}$ An anonymous reviewer made a correct remark that the examples (3b) and (3c) could involve certain N/NP movements to some lower positions.

${ }^{4}$ Under the appropriate context conditions, Macedonian and the Timok-Lužnice dialect of SC can allow these kinds of extractions (Stanković forthcoming). On the other hand, in Slovenian, a South Slavic language with no definite articles, such extractions are not acceptable. 
$\begin{array}{rlll}\text { (3) a. } & \text { devojke } & \text { ove } & \text { mlade } \\ \text { girls } & \text { these } & \text { young } \\ \text { b. } & \text { ove } & \text { devojke } & \text { mlade } \\ \text { these } & \text { girls } & \text { young } \\ \text { c. } & \text { mlade } & \text { devojke } & \text { ove } \\ & \text { young } & \text { girls } & \text { these }\end{array}$

(4) $\mathrm{Ovu}_{i} / \quad \mathrm{Lepu}_{i} \quad$ sam pronašla $\left[t_{i} / t_{j} \mathrm{knjigu}\right]$.

this-ACC.FEM.SG nice-ACC.FEM.SG AUX found book-ACC.FEM.SG

${ }^{*}$ This $_{i} /{ }^{*}$ Nice $_{j}$ I found $\left[t_{i} / t_{j}\right.$ book].'

(int.) 'It is $\{$ this book/the nice book $\}$ I found.'

Although all the data presented in (1)-(4) is correct, there are certain exceptions. In the remainder of the paper I will address these issues, demonstrating not just that under the appropriate conditions, SC speakers are compelled to use some sort of a definite/indefinite determiner, but also, that these adjective-like mandatory determiners have rather strict syntactic properties, in terms of syntactic position and blocking effects on adjective and adjunct extractions.

\section{Contexts demanding definite and indefinite determiners}

\subsection{Mandatory definite determiners}

As we have already seen in (1) in the previous section, SC bare NPs are, in most cases, ambiguous between a definite and an indefinite interpretation. SC lacks grammaticalized definite and indefinite articles, so, unlike in English, the speaker is not obliged to mark the discourse status of the nominal referent, using the mentioned indefinite pronouns (jedan 'a(n), one', neki 'some'), demonstratives/anaphoric pronouns (ovaj 'this', taj 'that', onaj 'that') or adjectives (pomenuti '(the) mentioned, navedeni '(the) stated', imenovani 'named', dati 'given', isti 'same', izvesni 'certain', odredeni 'particular'). Nevertheless, there are certain contexts in which the use of these determiners is obligatory to provide the intended reading. In this subsection I will demonstrate that in cases when the speaker wants to mark that the referents of two nominal phrases are identical, he/she is compelled to use an appropriate definite determiner.

Consider (5). It is an excerpt from a journal article on the scientific methods used in glottochronology. In the first sentence, the author is introducing a certain part of the lexicon present in every language, which 
is quite stable and convenient for this type of diachronic research. In the following sentence, the author is referring to the same part of the lexicon using the definite discourse marker (upravo) taj '(exactly) this'. This marker is actually not redundant, nor dispensable. In case a bare NP is used in the same context, it cannot denote the identical nominal referent, introduced in the previous sentence. It would simply add another referent, i.e., some other part of the lexicon. This means that the bare NP is not ambiguous, as expected, and that the use of a definite determiner is obligatory to obtain the intended definite interpretation of the nominal expression.

(5) Postoji [jedan izrazito stabilan dio rječnika $]_{i}$, koji se naziva exists one quite stable part lexicon which REFL. calls osnovno rječničko blago, a obuhvaća nazive dijelova tijela, tjelesnih basic lexicon treasure and comprises names parts body bodily osjeta i aktivnosti, pojava u prirodi, brojeve i zamjenice. senses and activities phenomena in nature numbers and pronouns

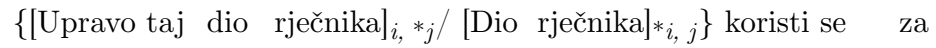
exactly this part lexicon-GEN part lexicon-GEN uses REFL for glotokronološka istraživanja.

glottochronological research

'There is a certain quite stable part of the lexicon, called basic lexicon treasure, comprised of appellatives for body parts, body senses and activities, nature phenomena, numbers and pronouns. \{Exactly this part of the lexicon/(Some) part of the lexicon\} is used for glottochronological research.'

(Tačno, 18.01.2015. $)^{5}$

Like (5), example (6) illustrates the fact that in certain contexts the absence of a discourse-old determiner triggers an epistemic specific indefinite interpretation of the phrase (as shown by the English translation containing the indefinite article). The curiosity of this example is that the bare NP does not present the nominal referent (previously established in the discourse) as accessible to the interlocutor. In order to achieve this, the speaker is obliged to use a definite determiner, such as taj 'that'.

(6) Naučnici i dalje nagađaju u vezi teorija nastanka svemira, scientists and further quess in relation theory genesis space od kojih je takozvani "veliki prasak" najpopularnija, i možemo from which is so-called big bang most popular and can je smatrati savremenim mitom, jer to zapravo jeste. Fizičari her consider contemporary myth because that actually is physicists

${ }^{5}$ http://www.tacno.net/novosti/snjezana-kordic-povijest-jezika/ 
$\left\{\right.$ [taj mit $\left._{i, *_{j}} /{\text { mit } *_{i, j}}\right\}$ nazivaju standardnim modelom svemira.

that myth myth call standard model space

'Scientists are still guessing with their theories on the genesis of space, of which the most popular one is the so-called "big bang" theory, which can be considered a contemporary myth, because it is one (a myth). Physicists consider this myth/some myth\} a standard model of space.'

(Vestinet, 17.11.2015.) ${ }^{6}$

Now, let us take a look at example (7). In the first clause of this sentence, a non-epistemic indefinite pronoun neko 'someone' is introduced to the discourse. In the fourth clause, the speaker refers to the identical referent, using the same pronoun and a mandatory definite determiner. In case the demonstrative $t a j$ 'that' is omitted, the only interpretation is that someone else, outside the set of referents established in the discourse, did the crime, which is a pragmatically unacceptable termination of the sentence.

(7) Ne možemo isključiti mogućnost da je zločin izvršio [neko not can exclude possibility that AUX crime commited someone

iz porodice $_{i}$, kome je žrtva verovala, ali sa kime

from family whom AUX victim trusted but with whom

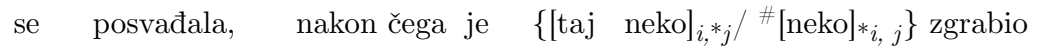

REFL started a fight after what AUX that someone someone grabbed

kamen i ubio je.

stone and killed her

'We cannot exclude the possibility that the crime was committed by someone in the family (some family member), someone who the victim trusted to, but with whom he/she got into a fight, whereupon \{that someone/someone\} grabbed a stone and killed him/her.'

(Informer, 25.05.2016. $)^{7}$

In all of the examples presented in (5)-(7), the definite nominal expression, marked by a mandatory determiner, constitutes the information topic. Unlike these, in the second clause of sentence (8), the discourse-old nominal, marked by a mandatory determiner, is part of the information focus. We find the same situation in the second sentence of example (9) and in the second sentence of example (10). This fact shows us that the obligatory use of definiteness markers in the illustrated contexts is not in correlation with information structure. Still, a common feature in the previous cases is that a bare NP is unambiguously interpreted as indefinite and it introduces new referents to the discourse.

${ }^{6}$ https://tinyurl.com/ybbmuy9b

${ }^{7}$ https://tinyurl.com/yd4vd73o 
(8) U to vreme je često putovao u inostranstvo, posebno in that time AUX frequently travelled in abroad especially u [Nemačku i Veliku Britaniju $]_{i}$, ali ne raspolažemo saznanjima o in Germany and Great Britain but NEG dispose knowledge about

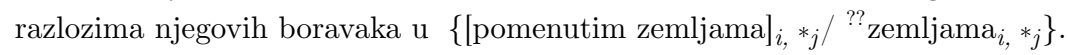
reasons his stays in mentioned countries countries 'In that period, he used to travel abroad frequently, especially to Germany and Great Britain, but we do not dispose the information about the reasons of his stays in the mentioned countries/countries\}.'

$(\text { Nedeljnik, 30.04.2016. })^{8}$

(9) Šešelj je predlagao Vuku Draškoviću formiranje zajedničke opozicione liste Šešelj Aux suggesting Vuk Drašković forming joint opposition list [SRS-a, SPO-a, DS-a i DSS-a $]_{i}[\ldots]$ Šešelj je nastavio pojedinačno SRS-GEN SPO-GEN DS-GEN and DSS-GEN Šešelj AUX continued individually

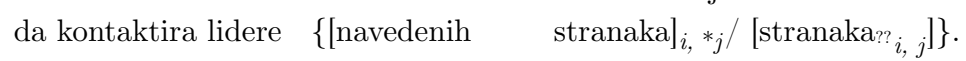
to contact leaders mentioned-GEN parties-GEN parties-GEN 'Šešelj was suggesting Vuk Drašković for a joint opposition list of SRS, SPO, DS and DSS to be formed [...] Šsešlj continued contacting the leaders of the mentioned parties/of parties\}.'

(Nedeljnik, 30.04.2016.)

(10) To je čovek koji šesnaest godina zaredom na sajmu $i$ skupi

that is man which sixteen years in a row on fair gather

3500 dečaka i devojčica. Đilas i ja smo poslednje

3500 boys and girls Đilas and I AUx last

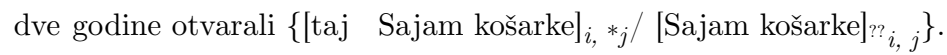

two years opened that fair basketball fair basketball

'That is a man who has been gathering 3500 boys and girls at a/the fair for sixteen years in a row. Đilas and I opened \{this Basketball fair/a Basketball fair $\}$ in the last two years.'

(Ekspres, 04.05.2016. $)^{9}$

In this subsection of the paper I demonstrated that the usual appraisal that bare nominals in article-less languages have ambiguous interpretations is not correct in all cases. We verified the claim that there are contexts in which the use of a bare nominal triggers an indefinite reading, therefore the speaker is compelled to use some definite determiner in order to trigger the appropriate definite interpretation, marking that the referents of two NPs are identical. In the following subsection I will present cases with the opposite discourse configuration, meaning, that we will deal with bare

\footnotetext{
${ }^{8}$ https://tinyurl.com/y8lo9s9s

${ }^{9}$ https://tinyurl.com/yd96yadb
} 
NPs that are unambiguously interpreted as definite unless some indefinite determiner is used to mark its indefinite discourse status.

\subsection{Mandatory indefinite determiners}

The most frequent cases of the mandatory use of indefinite determiners are to be found in sentences containing nominal expressions uttered outof-the-blue. If the referent of an NP has not yet been introduced into the discourse, in the appropriate contextual environment, such as (11), it can be unambiguously interpreted as definite. To be more precise, a bare nominal expression would bring a strong presupposition that its referent is already introduced to the discourse. ${ }^{10}$ In the last clause of the final sentence in (11), the speaker is using the indefinite determiner jedan ' $\mathrm{a}(\mathrm{n})$, one' to mark that the nominal is not part of the interlocutors' common ground. Otherwise, when uttered, the bare NP japanski naučnik 'Japanese scientist' would presuppose that its referent is mentioned by the speaker or that it is identifiable to the reader in some other fashion. ${ }^{11}$

(11) Danas je većina stručnjaka saglasna da postoji pet ukusa: today is majority experts-GEN consentient that exists five tastes slatko, slano, kiselo i gorko, plus ukus umami, koji sweet salty sour and bitter plus taste umami which je, pre nešto više od stotinu godina, prvi opisao AUX before something more than hundred years first described \{jedan japanski naučnik/ japanski naučnik\}.

one Japanese scientist Japanese scientist

'Today, the majority of experts agree that there are five different tastes: sweet, salty, sour and bitter, plus the umami taste, which was first described by \{some Japanese scientist/the Japanese scientist $\}$ some hundred years ago.' $\quad(\text { Vijesti, 15.05.2016. })^{12}$

Now let us turn to example (12). In this example, the common noun zemlja 'country' is marked as indefinite using the indefinite determiner jedna 'one'. The reason for this is the fact that, triggered by pragmatic mechanisms,

${ }^{10}$ Following Strawson (1950) in the assumption that the definite article in English language carries uniqueness presupposition (which does not affect the truth value of the entire proposition), I assume that, in the illustrated context, SC bare nominals also carry a presupposition that the nominal referent is unique in the relevant discourse.

${ }^{11}$ Another available interpretation is that the Japanese scientist is unique in the relevant discourse (i.e., that it has a weak definite reading, cf. Schwartz 2009).

12 https://tinyurl.com/y9sxfx83 
the bare nominal would bring a strong presupposition that the country that the author of the text is referring to is the native country of the interlocutors. Even if this was the case, but the intention of the speaker was to present the nominal referent as indefinite (as the case was with example (6) in the previous subsection), he/she would be compelled to use an indefinite determiner of some sort.

(12) Prvi put $\mathrm{u}$ istoriji Eurosonga \{jedna zemlja/ zemlja\}

first time in history Eurosong-GEN one country country

je izbačena sa takmičenja.

is expelled from contest

'For the first time in the history of Eurosong, \{some country/ the (our) country\} is expelled from the contest.'

$(\text { Novi, 22.04.2016) })^{13}$

The last example that we will examine in this subsection includes a proper noun/name. As commonly assumed, proper names bring a strong presupposition of uniqueness (and most often, presupposition of definiteness) of their referent in the relevant discourse. For this reason, when the hearer cannot identify its denotation and it is uttered out-of-the-blue, like the case is with (13), in SC the proper name has to be accompanied by some indefinite marker, such as jedan 'one' or izvestan 'certain'. If the obligatory indefinite determiner is omitted, the nominal referent is interpreted as identifiable to the interlocutor or given in the discourse.

(13) "Stalno slikate cipele i torbe, a neko ni za

always photograph shoes and bags but someone not for

leba nema", napisala je \{izvesna Milena/ Milena\} folk zvezdi

bread hasn't wrote AUX certain Milena Milena folk star-DAT

Seki Aleksić na Instagramu.

Seka-DAT Aleksić on Instagram

"'You always take pictures of your shoes and bags, but there are people who don't have enough money even to buy some bread", \{some person called Milena/Milena\} wrote to the folk star Seka Aleksić on Instagram.'

$(r t v b n, 27.8 .2015 .)^{14}$

${ }^{13}$ https://tinyurl.com/yc6blqh2

${ }^{14}$ https://tinyurl.com/yajw7v7l 


\subsection{Interim résumé}

In this section of the paper, I presented typical cases of contexts that impose the use of definite and indefinite determiners in article-less SC. We saw that the usual assumption - that nominal expressions without determiners in article-less languages are ambiguous regarding definiteness - is not absolutely correct, i.e., that there are certain discourse environments in which a bare NP is interpreted as either indefinite (section 3.1), or definite (section 3.2). In order to avoid the unintended reading of the nominal phrase, the speaker is forced to use some discourse marker of (in)definiteness.

Although these findings shed some new light on the discussion of the appropriate analysis of Serbo-Croatian NPs, as well as nominals in other article-less languages, it is important to notice that this argumentation is not sufficient for arguing in favor of a DP model for SC. This is simply because the offered data indicates that there are certain discourse configurations and pragmatic mechanisms that coerce the use of (in)definiteness markers. Nevertheless, one can still apply the bare NP model for the examples we examined in the previous two subsections, assuming that the mandatory "determiners" are plain discourse markers, which are to be analyzed as specifiers or left-adjoined adjectives, and not genuine D elements. This is why the data to be introduced in the following section is important for making our case for a DP analysis, at least when it comes to SC nominal expressions containing determiner-like elements.

\section{The syntax of SC mandatory determiners}

In this section, I will demonstrate that SC definite discourse markers are not just semantically similar to definite articles, but that they expose syntactic behavior typical of pre-nominal articles in languages with this category. First of all, the introduced discourse markers pomenuti '(the) mentioned, navedeni '(the) stated', imenovani 'named', dati 'given' and isti 'same' have the discourse-oriented, referential interpretation only if located at the initial position of the nominal expression (labeled herein as REF). The discourse-oriented, referential interpretation is meant to be understood along the following lines: the lexical semantics of the adjective is interpreted at the level of discourse, in the sense that the rest of the nominal expression has already been mentioned, stated, named, given or identical with the referent presented in the previous discourse. 
(14) a. navedeni $i_{\text {REF }}$ ogromni finansijski problemi stated huge financial problems 'the stated huge financial problems'

b. *ogromni navedeni ${ }_{\mathrm{REF}}$ finansijski problemi huge stated financial problems '*the huge stated financial problems'

If not located at the initial position of the phrase, the analyzed adjectives can only obtain their non-referential, descriptive reading, forming a part of the description. Unlike in (14b) (where the adjective navedeni 'stated' can only be interpreted as part of the description, and not as a definite discourse marker), at the initial position, these adjectives modify the referential expression (14a). This is why pseudo-oxymoronic phrases such as (15) are totally acceptable - their antonyms are interpreted at different semantic levels.

(15) gorepomenute REF $_{\mathrm{u}}$ emisiji nepomenute finansijske afere aforementioned in show not mentioned financial scandals 'the aforementioned financial scandals not mentioned in the show'

As one could expect from the asymmetry illustrated in (14), the reverse ordering of the antonyms is not possible:

$(16)^{*} u$ emisiji nepomenute gorepomenute $\mathrm{REF}_{\text {finansijske afere }}$

in show not mentioned aforementioned financial scandals

'the aforementioned financial scandals not mentioned in the show'

The analyzed discourse markers precede not just descriptive adjectives, but also comparatives and superlatives, as illustrated in (17). ${ }^{15}$ This fact suggests that they are positioned in some very high functional projection of the nominal skeleton. Namely, it is a well known fact that the comparative/superlative projections are merged on top of all adjective projections, from where they attract the appropriate adjective (Cinque 2010). In addition, it indicates that in their referential readings, these adjectives never appear in the comparative or superlative form (18), exactly like regular determiners. ${ }^{16}$

${ }^{15}$ The phrase in (17b) is acceptable only in the non-referential interpretation.

${ }^{16}$ SC D-elements and descriptive adjectives differ in this and other respect, as noticed by Frleta (2005) and Caruso (2012). 
(17) a. navedeni REF najveći godišnji prihod stated biggest year's income 'the stated largest income per year'

b. *najveći navedeni $i_{\mathrm{REF}}$ godišnji prihod biggest stated year's income

(18) imenovaniji $_{\mathrm{REF}} / *_{\text {najimenovaniji }}$ REF političar more named most named politician

Another important fact suggesting that discourse-oriented adjectives are located in a distinct, high-positioned functional projection is that they precede cardinal numbers in the analyzed readings. As a matter of fact, when preceding cardinals (19a), they are ambiguous between the referential and non-referential, descriptive interpretation (the latter, with a contrastive intonation, and presupposing the existence of discourse-old referents that do not satisfy the description). In post-cardinal position these adjectives can only have a non-referential interpretation (19b).

(19) a. data dva papira

given two papers

'the given ${ }_{\mathrm{REF}}$ two papers'

'the two delivered papers'

b. dva data papira

two given papers

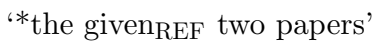

'(the) two delivered papers'

SC does not allow for full relative clauses to appear in pre-nominal position, therefore it is impossible to test whether the analyzed determiners precede pre-nominal relative clauses. Nevertheless, there is a strong indication that the presented mandatory determiners are not merged as (reduced) relative clauses ${ }^{17}$ - almost none of them can have a referential interpretation when found in the predicative position of a relative clause. As illustrated in (20)-(24), the only available interpretations for the adjectives imenovani 'named', dati 'given', isti 'same', izvesni 'certain' and odredeni 'particular' are the descriptive, non-referential ones. Given the fact that these adjectives cannot mark the discourse status of the modified NP when appearing in the predicative position of a relative clause, it is reasonable to assume that they are not merged as (reduced) relative

${ }^{17}$ I thank an anonymous reviewer for the remark that the analyzed adjectives could be merged as (reduced) relative clauses, unless this analysis could be refuted. 
clauses when used as discourse markers (see the discussion of examples (27)-(30) for more argumentation against this kind of analysis). ${ }^{18}$

(20)*Pričali smo o osobi koja je $\left\{*_{\text {imenovana }}\right.$ ReF / imenovana $\}$. talked-1PERS-PL AUX about person that is named appointed 'We talked about the person that $\{*$ is named/had been appointed $\}$.'

(21) Nevena je pročitala knjigu koja je $\quad\left\{{ }^{*}\right.$ data $_{\mathrm{REF}} /$ data $\}$. Nevena AUX read book that is/was given delivered

'Nevena read the book that $\left\{{ }^{*}\right.$ is given/had been delivered $\}$.'

(22) Cena koja je $\left\{{ }^{*}{ }_{\text {ista }}\right.$ REF / ista kao ranije $\}$ neće porasti narednog meseca. price that is same same as before will not increase next month 'The price that is $\left\{{ }^{*}\right.$ the very same/same as before $\}$ will not increase next month.'

(23) Una hoće da ide na ekskurziju koja je $\left\{*_{\text {izvesnaREF }} /\right.$ izvesna $\}$. Una wants to go on excursion that is certain expectable 'Una wants to go on an excursion that is $\left\{{ }^{*}\right.$ certain/expectable $\}$.'

(24) Nea će za Uskrs dobiti kućicu za lutke koja Nea will for Easter get house for dolls that je $\left\{{ }^{*}\right.$ određena ${ }_{\mathrm{REF}} /$ već određena $\}$. is particular already specified 'For Easter, Nea will get a doll house that is $\left\{{ }^{*}\right.$ particular/already specified.\}'

The analyzed determiners always precede possessives, as visible from example (25).

(25) Janku se dopadaju $\left\{{ }^{*}\right.$ moji izvesni $i_{\text {REF }} /$ izvesni $_{\text {REF }}$ moji $\}$ radovi. Janko-DAT REFL like my certain certain my papers 'Janko likes $\left\{{ }^{*}\right.$ my certain papers/certain papers of mine $\}$.'

${ }^{18}$ It is important to notice that the two adjectives that can obtain the referential interpretation when found in the predicative position of a relative clause, pomenuti '(the) mentioned' and navedeni '(the) stated', mark that the referent of the modified NP is an element of the set of the mentioned/stated referents available in the relevant discourse, implying that the presupposed set of mentioned/stated referents is not necessarily a singleton. On the other hand, when the same adjectives are used as pre-nominal determiners, they always bring a strong presupposition of uniqueness of the denoted nominal referent. This difference seems crucial in arguing that these two adjectives, when used as definite determiners, are not merged as (reduced) relative clauses either. 
The distribution of SC mandatory determiners is somewhat puzzling when their co-occurrence with demonstratives is considered. Namely, most of these discourse markers are in a complementary distribution with demonstratives (imenovani 'named', dati 'given', izvesni 'certain' and odredeni 'particular'), but some of them can appear in post-demonstrative position (pomenuti '(the) mentioned', navedeni '(the) stated' and isti 'same'):

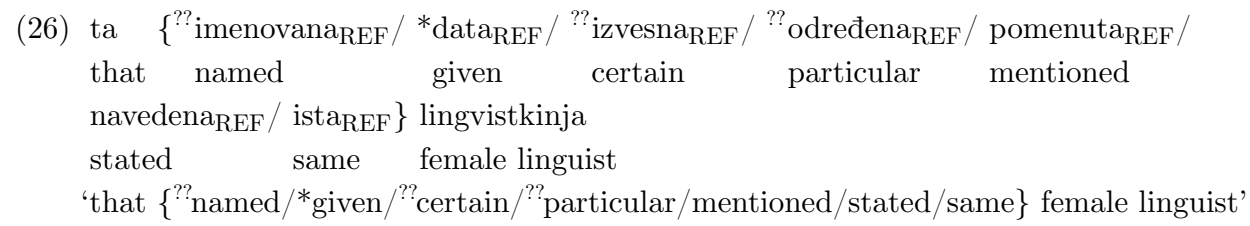

The data presented in (26) suggest that the position that some of the analyzed adjectives occupy (when used as determiners) is the same as the one taken by demonstratives, indicating that we are dealing with genuine D-items. On the other hand, some of these determiners are not in a complementary distribution with demonstratives, suggesting that they might occupy the specifier (demonstratives) or a head position (determiners) of some functional projection of the extended NP.

Finally, the most important indication that SC discourse markers are determiners that should be analyzed in a functional projection of the $\mathrm{D}$ type is the fact that they block left-branch and adjunct extractions, exactly like definite articles:

$(27){ }^{*}$ Interesantnu $_{i}$ sam preporučio datu deF $_{i} t_{i}$ literaturu.

interesting AUX recommended given literature

'*The given I have recommended interesting literature.'

(int.) 'It is the given interesting literature that I have recommended.'

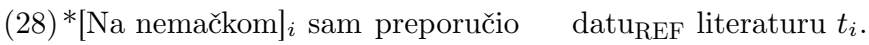

on German AUX recommended given literature

'*The given I have recommended literature in German.'

(int.) 'It is the given literature in German that I have recommended.'

As one could expect from the situation depicted in example (4) (in Section 2), in the non-referential interpretation, these adjectives allow both types of extraction, which is illustrated here in (29) and (30). Imagine a context in which the speaker had handed a stack of interesting and some boring books to his/her students, and then he/she recommended the subset of interesting ones for reading. Uttering (29), with a contrastive intonation on the extracted adjective would be acceptable. Similarly, ut- 
tering (30) would be perfectly fine in a scenario where the speaker has handed a stack of books written in German and some other languages to his/her students, subsequently recommending only the literature written in German.

(29) Interesantnu ${ }_{i}$ sam preporučio datu $t_{i}$ literaturu.

interesting AUX recommended given literature

'It is the interesting ones among the given literature that I have recommended.'

*'It is the given interesting literature that I have recommended.'

(30) [Na nemačkom $]_{i}$ sam preporučio datu literaturu $t_{i}$.

on German AUX recommended given literature

'It is the literature in German among those given that I have recommended.'

*'It is the given literature in German that I have recommended.'

The contrast depicted in (27)-(28) and (29)-(30) is another strong indication that SC mandatory determiners are not merged as (reduced) relative clauses. If this was the case, we would not expect any difference in the presence/absence of a blocking effect on left branch and adjunct extractions. However, the analyzed adjectives block these extractions only when utilized as discourse markers. This suggests that their syntax is different depending on their semantics, or rather, different syntactic placement triggers different semantic interpretation for these elements.

If we assume that all SC adjectives and non-personal pronouns are left adjoined to the noun, the question arises: how can we account for the evident differences in syntax, demonstrated in this section, and especially in (29) and (30)? If semantics, and not syntax, is responsible for the data presented (as argued by Bošković (p.c.) and Boškovič \& Gajewski 2011), we would expect that at least non-restrictive adjectives can precede referential adjectives. Nevertheless, this is not possible either with evaluative or expressive adjectives:

(31) a. $\left\{*_{\text {sjajni/ }}^{*}\right.$ prokleti $\}$ dati $\mathrm{REF}$ plesač

brilliant goddamn given dancer

'* $\{$ the brilliant/goddamn $\}$ given dancer'

b. dati $_{\text {REF }}\{$ sjajni/ prokleti\} plesač

given brilliant goddamn dancer

'the given $\{$ brilliant/goddamn $\}$ dancer'

As visible from (31), even evaluatives and expressives must follow the referential adjective, just like in languages with articles. Unlike the 'bare' NP analysis, a DP analysis could account for the entire set of data from this 
and the previous section. Namely, if we presume that SC discourse-oriented adjectives bear a D-feature, ${ }^{19}$ which allows them to move to the determiner projection and check the positively specified [definite] feature, then each piece of data presented in the paper obtains a plausible explanation. For instance, after merging in a functional projection dedicated to - what Sproat and Shih (1988) label as - indirect modification adjectives, the adjective dati 'given' moves to DP (presumably to SpecDP), and as a result, it receives the referential interpretation and blocks extractions, as already seen in (27) and (28). In case the same adjective stays in situ, it allows for both extractions, obtaining a regular, descriptive reading (29)-(30). When it comes to adjectives that can co-occur with demonstratives, they move to the head of DP, while the demonstratives occupy the SpecDP. Assuming that DP can remain phonologically null in article-less languages, one can conceive that the behavior typical of article-less languages is present only when DP is unsaturated, as seen in Section 2. But, in cases when the DP is "activated" by the presence of D-elements, it displays behavior that is (usually) attested in languages with articles. Once we adopt the possibility that article-less languages can project DP, other phenomena present in SC could elegantly be explained, as will be demonstrated in the next section of the paper.

\section{Restrictive post-nominal modifications}

Serbo-Croatian adjectives can take two different forms: a short one (traditionally labeled indefinite adjectival aspect, SAF hereafter) and a long adjective form (definite adjectival aspect, LAF), (32). The long form can mark the definiteness (discourse-old status) of the referent of the modified nominal expression in the canonic pre-nominal position, while the short one contributes to an unambiguously indefinite interpretation of the entire nominal expression (Leko 1999; Cinque 2010; Despić 2011; Stanković $2015 ; 2016 \mathrm{~b}) .{ }^{20}$ Nevertheless, the adjective modifier can also be generated in a reduced relative clause post-nominally, in the case where the expres-

19 The D-feature is present only on the analyzed adjectives (by virtue of their lexical semantics), but is not present on other $\mathrm{SC}$ adjectives, which prevents their movement to DP.

${ }^{20}$ Stanković $(2015 ; 2016 b)$ analyzes the so-called definite adjectival aspect, commonly labeled long adjective form, as a result of an agreement relation between the positively specified [definite] feature in the head of the individual and/or kind denoting DP, and the pre-nominal descriptive adjective - hence the ambiguity of the entire nominal phrase in (32) regarding individual/object denotation. For space limits reasons, this 
sion contains a post-adjectival PP. Post-nominal adjectives cannot take the long, definite adjectival form when followed by a PP, so the former remain in the default, short form (33). In a context in which the nominal referent is already introduced to the discourse, restrictive post-nominal short adjectives can only have the indefinite interpretation, i.e., they introduce a novel nominal referent, outside of the established singleton referent-set:

(32) \{uspešan- $\emptyset /$ uspešn-i\} gradonačelnik

successful-SAF successful-LAF mayor

' $\{[$ a successful], [a/the successful] $\}$ mayor'

(33) gradonačelnik \{uspešan- $\emptyset /$ *uspešni $\}$ na izborima

mayor successful-SAF successful-LAF on elections

'a/the mayor(,) successful on the elections(,)'

(34) $[\text { Otac Pera }]_{i}$ je bio veoma bolestan. Nažalost, nije stigao

father Pera AUX was very sick unfortunately NEG+AUX managed

da se rastane sa ocem $\left\{[\text { zaduženim do grla }]_{? ?}{ }_{i j}\right.$ /

to REFL say goodbye with father indebted to throat

$\left\{[\text {, zaduženim do grla. }]_{i / *_{j}}\right\}$

indebted to throat

'[Father Pera $]_{i}$ was very sick. Unfortunately, he didn't manage to say goodbye to his father $\left\{[\text { overburdened by debt }]_{? ?}{ }_{i j} /\left\{[\text {, overburdened by debt. }]_{i /{ }_{j}}\right\}\right.$ '

In (34), the nominal phrase otac 'father' is first introduced to the discourse and then the same noun appears in the second sentence, modified post-nominally with a restrictive and a non-restrictive adjective phrase with a PP adjoined. As apparent from the indices in (34), the expression with a post-nominal restrictive modifier can barely refer to the discourse-old nominal referent, so the only interpretation it can receive is one of introducing new referents to the discourse. Unlike the restrictive modification, the expression with the non-restrictive modification (signaled by the "comma" intonation) has a non-ambiguous definite reading. In these examples, the post-nominal modifying content is interpreted as providing additional, new information about an already established nominal referent.

One finds a similar situation in contexts with pre-nominally and post-nominally modified epithets. Epithets (also labeled as pseudo-anaphors) denote a referent already introduced into the discourse, but use some other description than the one employed in the primary discourse-

issue will not be discussed, but I direct the reader to the analysis proposed in these papers. 
entry. In SC, restrictive post-nominal modifications are unacceptable in epithets. Consider (35). ${ }^{21}$ In the first sentence of this example, the speaker is introducing the mayor of Niš. In the following sentence, an epithet with post-nominal modification and without a definite discourse marker cannot denote the same referent, i.e., the mayor of Niš.

(35) Na pres-konferenciju je stigao [gradonačelnik Niša $]_{i}$. [Političar sa doktoratom on press-conference AUX arrived mayor Niš-GEN politician with Ph.D.

iz oblasti medicinskih nauka $]_{?{ }_{i, j}}$ ima plan za oporavak privrede grada. from area medical sciences has plan for recovery economy-GEN city-GEN

'The mayor of Niš has arrived for the press-conference. A politician with a Ph.D. in medical sciences has a plan for a recovery of city's economy.'

There are two ways for the speaker to avoid this situation. One possibility is to employ a definite determiner, in which case the entire expression obtains a definite interpretation (36). Another option available is to use some pre-nominal modification. In this case, the choice of the adjective form (long vs. short) will disambiguate the expression; the short adjective form can only receive the indefinite reading, introducing a novel referent to the discourse, while the long form gives an ambiguous reading to the entire nominal expression (37).

(36) Na pres-konferenciju je stigao [gradonačelnik Niša $]_{i}$. Ovaj [političar sa on press-conference AUX arrived mayor Niš-GEN this politician with doktoratom iz oblasti medicinskih nauka $]_{i,{ }_{j}}$ ima plan za Ph.D. from area medical sciences has plan for oporavak privrede grada.

recovery economy-GEN city-GEN.

'The mayor of Niš has arrived for the press-conference. This politician with a Ph.D. in medical sciences has a plan for the recovery of the city's economy.'

${ }^{21}$ The same goes for English if a definite article is used (i), as demonstrated by Stowell (1981). Nevertheless, if a demonstrative is used (instead of the definite article) in the same context, then an epithet with a post-nominal modifier points to the referent already established in the discourse (ii). As a matter of fact, the demonstrative triggers an unambiguous discourse-old interpretation (if we disregard the colloquial use of this as a specificity marker, cf. Ionin 2006). Notice that the demonstrative here is a strong definite, in Schwarz's terms (2009). Space limitations prevent this issue from being addressed in the present paper.

(i) I tried to visit [the mayor $]_{i}$ last week, but [the angry old man $]_{i, j} /[$ the man angry at his constituents $]_{i, j}$ refused to see me.

(ii) I tried to visit [the mayor $]_{i}$ last week, but [this angry old man $]_{i, *_{j}} /$ [this man angry at his constituents $]_{i,{ }_{j}}$ refused to see me. 
(37) Na pres-konferenciju je stigao [gradonačelnik Niša $]_{i}\{[$ Visokoobrazovan- $\emptyset$ on press-conference AUX arrived mayor Niš-GEN highly educated-SAF političar ${ }_{* i, j}$, [visokoobrazovan- $\emptyset$ političar $\left.]_{i, j}\right\}$ ima plan za politician highly educated-LAF politician has plan for oporavak privrede grada.

recovery economy-GEN city-GEN

'The mayor of Niš has arrived for the press-conference. \{[A highly educated politician]/[A/The highly educated politician] $\}$ has a plan for the recovery of the city's economy.'

If we assume that article-less SC does project a DP with a [definite] feature that has to be checked, the examples above can easily be explained. The long and short adjective forms represent the result of a specific agreement between the adjective and the negatively or positively specified [definite] feature on the head of DP (Stanković 2015). Pre-nominal adjectives are in the domain of DP, so the agreement relation can be established, thus the positively specified [definite] feature can be checked, resulting in the possibility for the long form to be derived (32). Unlike these, post-nominal adjectives are not in the domain of DP, so the agreement relation is prevented and the adjective remains in its default, short form (33). The same analysis is applicable to epithets. The post nominal modifier in (35) cannot check the [definite] feature, yielding an indefinite interpretation. Unlike the post-nominal modifier, pre-nominal adjective modifiers are able to perform this operation by establishing the agreement relation, resulting in the definite interpretation of the entire nominal expression (37). In addition to the definite and indefinite adjectival aspect, there is another modus for checking the [definite] feature on the head of DP, and this is employment of definite (and indefinite) discourse markers, discussed in the previous sections and illustrated here in (36). Contrary to this approach, the bare NP analysis can hardly offer a satisfying explanation for the phenomenon. Once again, the proposed theoretical model covers a much larger portion of the data, with precise and accurate predictions. 


\section{Conclusion}

In this paper, I have addressed the issue of compulsory use of determiners in Serbo-Croatian, an article-less South Slavic language. The usual assumption that languages without articles employ bare nouns to obtain both definite and indefinite interpretations was shown to be inaccurate in certain contexts. We saw that there are discourse settings in which SC bare nouns are not ambiguous, as expected, and that sometimes they can unambiguously trigger either a definite, or an indefinite reading.

When one of these two scenarios is in play, the speaker is compelled to use an appropriate discourse marker, labeled as a "mandatory determiner" in this paper. But, this fact is not sufficient for arguing in favor of a DP analysis in an article-less language. In order to support this analysis, we needed syntactic and semantic indications for the existence of a distinct functional projection located higher than NP, which would exhibit behavior similar to the definite article in languages with this category. Thus, the class of discourse-oriented, referential adjectives pomenuti '(the) mentioned, navedeni '(the) stated', imenovani 'named', dati 'given', isti 'same' were introduced. These belong to this set of (very often, mandatory) determiners. First of all, semantically, they are close to definite articles, because they are regularly used to indicate that the nominal referent is already mentioned, stated, named, given or the same as (i.e., identical with) the referent already established in the relevant discourse. But, more than that, their syntactic properties showed more interesting in this discussion. Namely, with their rigid ordering in the nominal phrase (always in the initial position, preceding all other adjectives, comparatives/superlatives, possessives, cardinal numbers, as well as non-restrictive adjectives), their non-predicative nature and the fact that they allow for pseudo-oxymoronic combinations, while blocking left-branch and adjunct extractions, they suggest that some functional projection of the D type might be projected even in a language without grammaticalized articles. The same adjectives, when used in their non-referential reading, do not exhibit these properties. If one assumes that all SC adjectives and non-personal pronouns are left-adjoined modifiers, or specifiers, this asymmetry is unexpected.

Once we adopt the possibility that DP might be projected, even in a language without articles, other phenomena receive plausible explanation. We saw obvious asymmetries in the possibility for post-nominal and pre-nominal modifiers appearing in epithets. This fact was interpreted as a consequence of the fact that the [+definite] feature located on the head of DP can be checked only by pre-nominal modifiers. As for the alterna- 
tive, bare NP analysis, it could hardly offer a plausible explanation for the semantic difference present on left and right adjoined modifiers. More than that, it fails to explain the blocking effects which discourse-related adjectives trigger only in their referential readings and the fact that even non-restrictive adjectives must follow referential adjectives. This is unexpected, if only semantics is responsible for the rigid word ordering in the presence of (mandatory) definite determiners, as argued by the opponents of the DP approach.

\section{References}

Aljović, Nadira. 2000. Recherches sur la morpho-syntaxe du groupe nominal en serbocroate. Doctoral dissertation. Université Paris 8.

Aljović, Nadira. 2002. Long adjectival inflection and specificity in Serbo-Croatian. Recherches Linguistiques de Vincennes 31. 27-42.

Arsenijević, Boban. forthcoming. Atypical demonstratives in an articleless language. In E. Boeff, M. Coniglio, E. Schlachter and T. Veenstra (eds.) Demonstratives. Berlin \& New York: Mouton de Gruyter.

Boškovič, Željko. 2008. What will you have, DP or NP? In E. Elfner and M. Walkow (eds.) Proceedings of the 37th Annual Meeting of the North-East Linguistic Society. Volume 1. Amherst: Graduate Linguistic Students' Association, University of Massachusetts. 101-114.

Boškovič, Željko. 2012. On NPs and clauses. In G. Grewendorf and T. E. Zimmermann (eds.) Discourse and grammar: From sentence types to lexical categories. Boston, MA \& Berlin: Walter de Gruyter. 179-242.

Boškovič, Željko and Jon Gajewski. 2011. Semantic correlates of the NP/DP parameter. In S. Lima, K. Mullin and B. Smith (eds.) Proceedings of the 39th Annual Meeting of the North East Linguistic Society (NELS 39). Amherst: Graduate Linguistic Students' Association, University of Massachusetts. 121-134.

Caruso, Đurđica Željka. 2011. In support of a DP-analysis of nominal phrases in Croatian. Paper presented at the Workshop on Languages with or without Articles, Paris, March 2011.

Caruso, Đurđica Željka. 2012. The syntax of nominal expressions in articleless languages: A split-DP analysis of Croatian nouns. Doctoral dissertation. University of Stuttgart.

Cinque, Guglielmo. 2010. The syntax of adjectives: A comparative study. Cambridge, MA: MIT Press.

Corver, Norbert. 1990. The syntax of left branch extractions. Doctoral dissertation. Tilburg University.

Corver, Norbert. 1992. On deriving certain left branch extraction asymmetries: A case study in parametric syntax. In K. Broderick (ed.) Proceedings of NELS 22. Amherst: Graduate Linguistic Students' Association, University of Massachusetts. 67-84.

Despić, Miloje. 2011. Syntax in the absence of determiner phrase. Doctoral dissertation. University of Connecticut. 
Despić, Miloje. 2013. Intensifiers, focus, and clitics: Is pronoun position truly an argument for D in Serbo-Croatian? In L. Schürcks, A. Giannakidou, U. Etxeberria and P. Kosta (eds.) Nominal constructions: Slavic and beyond. Berlin \& New York: Mouton de Gruyter. 150-186.

Frleta, Tomislav. 2005. Razlika između determinanta i opisnog pridjeva [The difference between determiners and descriptive adjectives]. Suvremena lingvistika 59-60. 71-80.

Heim, Irene. 1983. File change semantics and the familiarity theory of definiteness. In R. Bäuerle, C. Schwarze and A. von Stechow (eds.) Meaning, use, and interpretation of language. Berlin \& New York: Mouton de Gruyter. 164-189. (Reprinted in: P. Portner and B. H. Partee (eds.): Formal semantics: The essential readings, Oxford \& Malden, MA: Blackwell, 2002.).

Ionin, Tania. 2006. THIS is definitely specific: Specificity and definiteness in article systems. Natural Language Semantics 14. 175-234.

Kuna, Branko. 2003. Np-pomicanje i posvojni genitiv [NP-movement and the possessive genitive]. Jezikoslovlje 4. 245-261.

Leko, Nedžad. 1999. Functional categories and the structure of the DP in Bosnian. In M. Dimitrova-Vulchanova and L. Hellan (eds.) Topics in South Slavic syntax and semantics. Amsterdam \& Philadelphia: John Benjamins. 229-252.

Pereltsvaig, Asya. 2007. On the universality of DP: A view from Russian. Studia Linguistica 61. 59-94.

Progovac, Ljiljana. 1988. Determiner phrase in a language without determiners. Journal of Linguistics 34. 165-179.

Runić, Jelena. 2013. Cliticization phenomena in languages "on the border". University of Pennsylvania Working Papers in Linguistics 19. 177-188.

Russell, Bertrand. 1905. On denoting. Mind 14. 479-493. (In: B. Russell: Logic and knowledge. London: Routledge. 39-56).

Rutkowsky, Paweł and Ljiljana Progovac. 2005. Classification projection in Polish and Serbian: The position and shape of classifying adjectives. In S. Franks, F. Y. Gladney and M. Tasseva-Kurktchieva (eds.) Formal approaches to Slavic linguistics 13: The South Carolina meeting. Ann Arbor, MI: Michigan Slavic Publications. 289-299.

Schwartz, Florian. 2009. Two types of definites in natural language. Doctoral dissertation. University of Massachusetts, Amherst.

Sproat, Richard and Chilin Shih. 1988. Prenominal adjectival ordering in English and Mandarin. Proceedings of the North Eastern Linguistic Society (NELS) 18. 465-89.

Stanković, Branimir. 2014. Arguments for DP-analysis of Serbo-Croatian nominal expressions. In L. Veselovská and M. Janebová (eds.) Nominal structures: All in complex DPs. Olomouc: Palacký University. 29-48.

Stanković, Branimir. 2015. Sintaksa i semantika određenog i neodređenog pridevskog vida $\mathrm{u}$ srpskom jezika [Syntax and semantics of definite and indefinite adjectival aspect in Serbian]. Doctoral dissertation. University of Kragujevac.

Stanković, Branimir. 2016a. Adjectives at the left periphery as an indication of a DP in Serbo-Croatian. In K. Bellamy, E. Karvovskaya, M. Kohlberger and G. Saad (eds.) ConSOLE XXIII: Proceedings of the 23rd ConSOLE. Leiden: Leiden University Centre for Linguistics. 294-316. 
Stanković, Branimir. 2016b. DP in a language without articles - the case of Serbo-Croatian adjectives. Paper presented at the Workshop on the Semantic Contribution of Det and Num. (In)definiteness, genericity and referentiality, Universitat Autònoma de Barcelona, May 27-28, 2016.

Stanković, Branimir. forthcoming. DP or NP? The case of Serbian southeastern dialects and Macedonian language. In B. Stanković and A. Janić (eds.) Proceedings of SinFonIJA 6. Niš: University of Niš, Faculty of Philosophy.

Stowell, Tim. 1981. Origins of phrase structure. Doctoral dissertation. MIT.

Strawson, Peter Frederick. 1950. On referring. Mind 59. 320-344.

Trenkić, Danijela. 2004. Definiteness in Serbian/Croatian/Bosnian and some implications for the general structure of the nominal phrase. Lingua 114. 1401-1427.

Zlatić, Larisa. 1997. The structure of the Serbian noun phrase. Doctoral dissertation. University of Texas, Austin.

Zlatić, Larisa. 1998. Slavic noun phrases are NPs not DPs. Paper presented at the Workshop on Comparative Slavic Morphosyntax, Bloomington, Indiana, June 8, 1998. 